$\angle$ Research Square

\title{
COP Adoption, Implications and Projections of Climate Change Mitigation Policy for ASEAN Region
}

adeel ahmed ( $\square$ adeelawan261@gmail.com )

National University of Sciences and Technology https://orcid.org/0000-0001-7439-9606

Abul Quasem Al-Amin

University of Waterloo Faculty of Environment

Md. Mahmudul Alam

Universiti Teknologi Malaysia - Main Campus Skudai: Universiti Teknologi Malaysia

Brent Doberstein

University of Waterloo Faculty of Environment

\section{Research Article}

Keywords: Adoption, Implications, Projections of Climate

Posted Date: June 17th, 2021

DOl: https://doi.org/10.21203/rs.3.rs-549288/v1

License: @ (1) This work is licensed under a Creative Commons Attribution 4.0 International License. Read Full License 


\section{Abstract}

Climate Change is a critical concern for Southeast Asia as this region is extremely vulnerable to the extreme weather patterns, temperature fluctuations and uneven precipitation expected under climate change, and thus vulnerability is expected to increase in the future. With this background, this study aims to analyze the readiness of ASEAN member countries to undertake the promised determinants of INDCs by the Paris Agreement and transfer these into measurable actions, and also to explore how ASEAN nations may reduce climatic threats over time. Consequently, a long run RICE (Regional Integrated Climate and Economy) based dynamic nonlinear numerical model for the economy and environment was utilised. Simulation forecasts investigated several alternatives in order to determine optimal climate strategies against global-warming in the region, using both an Optimal Scenario (OS) and Business-asusual (BAU) projections from 2020 to 2060. The results indicate that under an optimal scenario, industrial emissions are estimated in monetary values, RM14.05 (US\$1=RM4.30)(btCO2 per year) in 2040 and RM31.99 (btCO2 per year) by 2060. These estimated values under OS are striking for sustainable development since they are far lower than BAU projections. Carbon price (RM per tCO2) by OS indicates that the carbon tax could be RM224.65 in 2040, RM258.16 in 2050 and RM245.41 in 2060 per tCO2. The collected carbon tax can be reinvested by ASEAN nations in order to implement alternative backstop technologies and technological innovation. The optimal scenario outcomes examined for carbon emission reduction are tempting since they can support a strong balance between sustainable development and quality environment. Despite long-run economic assumptions, the findings are still a worthy means by which ASEAN governments can compare climate change mitigation strategies while also making amendments for any unexpected developments.

\section{Introduction}

According to the report of the Green Gas Bulletin circulated by the World Meteorological Organization (WMO, 2015), the accumulation of key greenhouse gases including $\mathrm{CH}_{4}, \mathrm{CO}_{2}$, and $\mathrm{NO}_{2}$ in 2014 had an average concentration of $1833 \times 10^{-6}, 397.7 \times 10^{-9}$, and 327.1x $10^{-9}$, respectively. Concentrations of those gases compared to preindustrial levels show an average increase of $254 \%, 143 \%$, and $121 \%$, respectively. It is evident from IPCC (Intergovernmental Panel on Climate Change) studies that those gases are the main cause of climate change and global warming (IPCC, 2014). Other more recent scientific studies on climate change also mention similar outcomes for the major greenhouse gases known to cause climate change (Hertzberg et al., 2017; Auffhammer, 2018; Rasiah et al., 2018; Manabe, 2019; Seddon et al., 2020). The fifth evaluation report of IPCC (AR5) demonstrates that the world is continuing to warm due to anthropogenic GHG emissions (Edenhofer et al., 2014; IPCC, 2014), and the continuous warming is linked to fossil fuel and conventional energy utilisation (Boeker \& Van Grondelle, 2011; Owusu \& Asumadu-Sarkodie, 2016). Over the decades, the usage of fossil fuels associated with industrial development increased at an annual rate of approximately $2 \%$ (Ritchie \& Roser, 2020). The world $\mathrm{CO}_{2}$ emissions from energy utilisation have been projected to increase at an annual average rate of $1.0 \%$ between the periods of 2012-2040 (IEA, 2016). On average, annual emissions from OECD countries have increased by approximately $0.3 \%$ while non-OECD countries have increased by almost $1.5 \%$, and it is anticipated that the latter trend will increase further (Salahuddin et al, 2016). Eventually, there will be a serious threat to society and ecosystems, which highlights the importance of taking action to mitigate climate change by reducing GHG emissions (Seddon et al., 2020). The IPCC in its AR5 study assessed 193 published emissions scenarios derived from several models, and then proposed that the world temperature should not rise more than $2^{0} \mathrm{C}$ to restrict global warming. The AR5 also proposed to limit CO2 ppm within a range 415 to 460 ppm by 2100, or lowering emissions from 35 to $55 \%$ by 2050 compared to 1990 levels in order to limit climatic impacts (Rogelj et al., 2011).

According to Fu (2007), Yao et al. (2011), and Sun et al. (2012), climatic systems are very complex, and many anthropogenic and ecological factors are involved. Likewise, scientific ambiguity occurs frequently when attempting to predict the real consequence of global warming on ecological systems, due to the unavoidable challenges of trying to do long-term evaluations of impacts and make factual predictions (Hamilton et al., 2018). Gao (2016) states that to lessen climatic effects, it is important to re-orient several key sectors including energy, transport, and industry, since those have high mitigation potential. Those sectors turn into huge economic and social costs as well and place an excessive burden for each country for the right energy mix policy (e.g. lowering carbon emission) and sustainable energy development (Francesch-Huidobro, 2016). Sachs (2015) states that clarification on the mitigation of climatic issues can be defined by two basic important concepts, namely - climate change itself, and economic development. Climate change is one of the defining issues of recent times and it is clearly integrated with economic development and associated impacts (Klepp, 2017). Changes in climate have a strong influence on economic development and human life (Holden et al., 2017). On the other hand, when defining the magnitude of economic development, economic indicators such as the growth rate of GDP, 
population and consumption of energy are used (Kok et al., 2008). Thus, there is a linkage always found between economic development and climate change (Rasiah et al., 2018).

The achievement of economic growth creates additional energy demand and drives energy consumption globally (Li et al., 2019). Thus, both the developing and least developed countries are in a perpetual race for so-called "development" which is essentially trying to confirm additional energy demand because of its goal to long-term economic development, growth and expansion in the global market (Wen-Cheng Lu, 2017). This puts us in a rat race state, where every nation is trying moving ahead over others in the pathway of development considering the creation of a new source of energy to support the economic development, however, conventional energy (fossil fuels) remains for energy development (Foo, 2015). Eventually, it has been scientifically proven that fossil fuels (like oil, coal and other conventional energy sources) consumed to provide energy for development, emit carbon-di-oxide (e.g. commonly known as carbon emission) and other GHGs which are the main contributors to climate change (Cai et al., 2018).

Nobel Prize nominee Lord Stern (2007) and winner Nordhaus (2008), both claim using scientific evidence that climate change is almost entirely arising from the substantial use of fossil fuels and from other unsustainable human activities. These authors further state that over the coming decades, long-term changes of climate will depend mostly on the total quantity of carbon and other GHG gases released from fossil fuel combustion. During the $20^{\text {th }}$ century, it has been estimated that every year approximately thirty billion tons of carbon-di-oxide are released from the combustion of fossils fuels and the majority enter the atmosphere leading to increasing concentrations of GHG gasses as the main contributor to global climate change (IEA, 2015). As the concentrations of GHG increase in the atmosphere, the more heat is trapped and the more the earth is warmed. The reality of climatic effect due to carbon-di-oxide from the combustion of fossils fuels we are facing today will continue to increase further unless there is an intervention (Rasiah et al., 2017).

There is also an indication at the country level of a significance destructive climatic change due to global carbon emission concentrations, and effects can be found to be linked both directly and indirectly (Nordhaus, 2001; Bonfils et al., 2008; O'Neill et al., 2014). Direct climatic impacts include degradation of the environment, impacts on ecology, declining natural resources, destruction of infrastructure, and impacts on health. Moreover, there are also numerous indirect impacts, which are expected to be severe over the long-run and can be more severe in some aspects than the direct impacts of climate change (Al-Amin \& Filho, 2014). Increased GHG gas concentrations in the air reflects has been linked to rising sea levels, warmer global air temperatures, rising average global ocean temperatures, melting of ice sheets and snow, and many impacts on various species all over the world (Mycoo et al., 2017; Vousdoukas et al., 2017; Nerem et al., 2018). It is contended that the sea level will rise on average by about $16.5-53.8 \mathrm{~cm}$ by 2100 while average global temperatures will rise from 1.1 to $6.4^{\circ} \mathrm{C}$ (Bernstein et al., 2007). Thus, both can threaten the existence of half the world's population who live in coastal areas (Lau et al., 2010; Walsh et al., 2012). Both advanced developing countries and least developed nations are equally vulnerable, especially African and South Asian nations which are considered as most vulnerable (AlAmin \& Filho, 2014). Many countries have acknowledged recent scientific evidence about the effects and impacts of climate change, and have taken action or are planning to take action to reduce their vulnerability to climatic change (Rasiah et al., 2017).

Some contemporary studies have also identified that the ASEAN region can also be highly vulnerable due to the limited climate mitigation actions in the region (Francisco, 2008; Yusuf \& Francisco, 2009; Uy et al., 2010; Amran et al., 2016; Rasiah et al., 2018). ASEAN's vulnerability stems in part from its long coastline of about $173,000 \mathrm{~km}$, and a high density of population which was around 650 million in 2016 (World Bank, 2017). ASEAN is also made up of several member countries that are greatly dependent on industry and agriculture to maintain economic development and growth, while at the same time experiencing rapid and largescaledeforestation (Hoad, 2015). Most of the ASEAN member countries are struggling to balance economic growth and sustainable development due to their uncertain and sometimes precarious developmental positions (Rasiah et al., 2017).

This paper contends that the more ASEAN member countries look for economic growth, the more they will face climate vulnerability unless there is an intervention which steers these countries toward low carbon pathways (Figure 1). Thus, this study begins with the assumption that climate vulnerability is linked to ASEAN member countries' limited mitigation capacities, and the study investigate several alternatives by modelling simulations (e.g. Optimal Scenario (OS) vs Business-as-usual (BAU) forecasts) from 2020 to 2060 in order to determine optimal climate strategies that can buffer climate change effects in the region.

The likely activities and strategies against the vulnerability of climatic change in the ASEAN region are addressed in the following sections. 


\subsection{INDC Submission by ASEAN Nations}

Most ASEAN nations are low and middle income emerging countries, and some of them are undergoing rapid economic development along with a rapidly expanding consumption of energy. Moreover, there is a demand for additional sources of energy in the future in order to maintain expansion in power and electricity utilization (Ang \& Goh, 2016). Consequently, the potential for increased $\mathrm{CO}_{2}$ emissions is likely in this region, and these higher energy demands will result in additional contributions to global warming which are expected to increase the frequency of catastrophic environmental consequences such as floods, storms and droughts. As addressed long ago by Hardin (1968), a collective realization that the environment is a common good globally means that countries all over the world will be affected if emissions are generated anywhere. All ASEAN nations have now adopted a key international climate agreement known as the '2015 Paris Climate Accord' under the U.N. Framework Convention on Climate Change (UNFCCC, 2015) referred to as the Conference of the Parties or "COP21" (Rasiah et al., 2018). Under the Accord, all countries know what climate action measures must be taken after 2020 under the new international treaty as determined by their Intended Nationally Determined Contributions (INDCs) (Rasiah et al., 2017).

ASEAN nations are all bound by the similar limits within the INDCs and these confirm that all national governments have to take action for climate mitigations measures based on their respective national or country-specific mitigation strategies. The climate mitigation actions specified in the INDCs are aimed at attaining the long-run goals of the Paris climate agreement, with 2030 set as the agreed medium-term deadline (i.e. agreed at COP21 and followed up via theCOP22-24 meetings) to meet climate mitigation targets, and 2050 set as the long-term deadline for a stronger commitment (i.e. additional voluntary reductions). Individual ASEAN nation capacities and contexts for meeting both the 2030 and 2050 targets are uneven (Rasiah et al., 2017). Therefore, the actions described in INDCs are essential in making sure the promised mitigation of climate change takes place in each of these ASEAN nations. The reality is, good practice is a prerequisite for success in such long term INDCs, intended actions. The INDCs reduction targets for each of the ASEAN countries is illustrated in Table 1.

In line with INDC reduction targets, the ASEAN community is working together to keep the global average temperature rise below $2^{0} \mathrm{C}$ and to increase their national capabilities to regulate the adverse effects of a changing climate (Rasiah et al., (2018). Many countries in the region plan to foster resilience in their development path in such a manner so that the production of food and in economic development generally does not add additional GHG emissions, and increase climatic resilience (Rasiah et al., 2017). Accordingly, many ASEAN countries have submitted their INDC plans for reducing carbon emissions by a certain level by 2050 , most by trying to achieve $8-36 \%$ reduction by their own efforts, and another 5-17\% mainly with the help of carbon financing from developed and advanced countries (Rasiah et al., 2018).

\subsection{Nature of INDC and National Climate Mitigation Policies}

ASEAN climate change mitigation efforts need to be seen against a global context. The Global Energy Demand and $\mathrm{CO}_{2}$ Status Report (2017) mentioned that global $\mathrm{CO}_{2}$ emissions from energy grew in 2017 by $1.4 \%$, equivalent to 460 million tonnes (Mt) which were the result of robust global economic growth of 3.7\%, and linked increases in energy demand globally of $2.1 \%$ (IEA, 2018). The report also projected that global energy demand would rise by about $35 \%$ by 2040 , and that energy would still continue as the largest source of demand for energy until 2040. Natural gas is expected to be replaced by coal as the second-largest energy source by the year 2025 (IEA, 2018). Natural gas, oil and coal will continue in their dominant role in supplying power in the long-run agendas a whole, these three fuels are expected to supply nearly $80 \%$ of the total global power until the period of 2040 . The report further states that although the United Kingdom, United States, Japan and Mexico have recently experienced a stable trend in $\mathrm{CO}_{2}$ emission, most of the other major economies saw an increasing trend (IEA, 2018). The biggest increase came from Asian and South-east Asian economies which accounted for almost two-thirds of the total increase in carbon emissions globally (Bakhtyar et al., 2013; Wang et al., 2016, Olivier et al., 2017).

The recent growth in energy-related $\mathrm{CO}_{2}$ emissions demonstrates that the mitigation efforts already implemented are not yet sufficient to meet the targeted climate objectives effectively (Al-Amin et al., 2015). Without significant change, there will be a vast gap even with the Paris climate agreement between reality and climate change goals (Bodansky, 2016). Many research works have estimated that due to the utilization of coal power for a reasonable coincidental demand in developing countries, the total GHG gasses must be topmost soon (Jewell et al., 2019). However, there is no alternative of green energy utilisation in the most developing countries against coal power to be maintaining the INDCs and by 2030 the utilization of coal power must be shut (Al-Amin et al., 2015;

Page $4 / 18$ 
Vandenbergh \& Gilligan, 2017). If the right trajectory is not taken by 2030 , all hope of limiting global temperature rise to just $1.5^{0}$ will be absent, and a rise of $2^{0}$ or more will almost definitely occur. Thus, the Marrakech Declaration (UNFCCC, 2016) that "nothing can stop global climate action" should heeded and accelerated to bring the provisions of the Paris Agreement into effect as well as seeking to pursue more drastic routes (Rasiah et al., 2018; Ahmed et al., 2019, Sarkar et al, 2019).

In light of the discussion above, there are numerous routes that policymakers can follow, as evidenced by an increasing number of scientific papers suggesting action against climate change (Al-Amin et al., 2015; Rasiah et al., 2017; Ahmed et al., 2019; Sarkar et al, 2019). As early as 2008, Yang et al. (2008) outlined three routes that could ensure economic growth without environmental damage: (i) the reduction of carbon intensity; (ii) increased energy intensity, and; (iii) enhancement of carbon sequestration. The first route involves using energy efficiently, as explained in several early studies (Herring, 2006; Palm \& Thollander, 2010). The second route entails shifting to renewables as has been suggested by many researchers (Murillo et al., 2003; de Vries et al., 2007; Patiño et al., 2008; Serrano-Ruiz \& Dumesic, 2011; Patiño et al., 2016). Finally, the third route includes developing technology to capture and store more $\mathrm{CO}_{2}$ emissions (Míguez et al., 2018). All suggested routes will facilitate the revolution required - a new energy system for humans to turn away from industrial civilization in favour of an ecological civilization (Muradov, 2014).

The failure to achieve an ecological civilization will cause permanent damage to the environment and prevent future societies from being able to bridge the gap between industrial and ecological civilization (Read, 2016). Therefore it is vital to investigate the nexus between economic growth and climate change, regardless of whether this occurs in developed or developing countries - both share a similar global climate concern (Cai et al., 2018). More attention is essential in order to stabilize GHG emissions and concentrations, and limit climate change. It is time for the world leaders to enforce and drive zero GHG emissions (Bataille, C. G. (2020). Thus, discussions regarding the mitigation of global climate change require actions on INDCs from all parts of the world (Burch et al., 2007; Keohane \& Victor, 2016). Hence, the nature of INDCs includes the following issues for mitigating climate change:

1. Featuring or understanding trends in climate change

2. Identifying the mitigation capabilities of domestic firms

3. Ensuring support from institutions

4. Improving the structure of energy infrastructure

5. Adapting right energy policy

6. Advancing green technologies

The argument against GHG emissions lowering was more sophisticated in policy circles supported by the inverted Kuznets's environmental "U" shaped curve (Penayato, 1997) which implies that marginal utility of environment is deemed as low at the earlier stage of development in any nation, and hence, the intensity of emission increase fast as the national income goes up. The arguments follow the propositions; - (i) emission intensities increase until a definite threshold of income is reached; (ii) the marginal utility of environment equals the marginal benefit from $\mathrm{i}^{\text {th }}$ income, and emission intensity falls as income increases, and hereafter the utility of environment continues to expand with an additional income. The environmental " $U$ " shaped curve can be overcome once there is a green innovation taken place all over with the concept of 'Limits to Growth' regardless of boundaries.

Contrary to the Limits to Growth thought led by the Club of Rome originally addressed by Meadows et al. (1972) follow some contemporary scientists still as indicated by an earlier study by Panayotou (1997), and recently by Sachs (2015). They established that trade-off between climate change and economic growth which requires huge efforts is always not mandatory since alternatives are obtainable by backstop technology (Stern, 2007; Nordhaus, 2008). Specifically, the findings from Nordhaus (2008) and assumptions regarding climate change as stated by Stern (2007) are investigated and verified persistently in recent times. Some areas of active discussion and research ongoing include the link between the amount of ocean heat and the warming rates, estimation of how much warming is expected to be soon, and the link between climate change and risky weather conditions (Wijffels et al., 2019). Nevertheless, understanding of climate differences on regional to local spatial spans and understanding of centennial to decadal spans are still limited (James et al., 2017). It is thus important to understand how regional climate affects global and global climate affects regional level. All of these scopes are hot areas of contemporary researches. Accordingly, Paris climate agreement in 2015 indicated for the world leaders that all countries must know what climate measures they have to take globally and individually after 2030 by their Intended Nationally Determined Contributions (INDCs). 
This study attempts to explore the preparedness of ASEAN nations to translate the promised INDCs into measurable actions, and then determine how those actions might mitigate climate change threats in this region. This study also provides suggestions about whetherit is necessary to alter the proposed INDC's, and whether there are any special areas of focus needed as fundamental and urgent considerations. Since ASEAN countries are yet to start ecologically bearable emission thresholds, thus a sustainable climate reduction target is essential. Yet even ASEAN has no right blueprint to proceed to reduce carbon emission regionally against climate change. However, some researchers suggest that developing a blueprint for a low carbon environment is challenging in ASEAN for many reasons (Rasiah et al., 2017; Rasiah et al., 2018; Sarkar et al, 2019). Firstly, the ASEAN regions include a wide range of developed, developing and least developed countries. Secondly, ASEAN encompasses many dynamic economies that have grown rapidly in recent years, but it is uncertain how much of this growth will be sustained over the coming years, and by extension, how much increased conventional energy demand will be in the coming decades. Thirdly, ASEAN countries are very diverse regarding culture, politics, governance and resources, all of which have implications for climate change mitigation efforts.

As stated above with scientific evidence, it is now more definite than ever that achieving higher and sustainable economic growth is changing earth's climate that can affect generations being a reasonable citizen of ASEAN. The atmosphere and oceans have warmed with sea-level rise, Arctic sea ice has declined, and other climate-related changes humans are embracing continuously (DeConto \& Pollard, 2016). The evidence is clear in the contemporary period. However, as a result of the nature of science, every single aspect of climate change is not ever settled totally or entirely certain and each relevant question has not yet been answered with strength. Therefore, we need to continue to gather scientific evidence that needs to make useful policy decisions to lower the level of climate change and adapt to its effects consistently.

With this background, this study examines an ASEAN "optimal strategy" against climate change and explores climate change-related impacts over the long run by modelling interventions. Specifically, to recognize the importance of climate mitigation, targets have been prepared for ASEAN by Optimal Scenario (OS) projections which compared with Business as usual (BAU) scenarios so that all individual countries can observe their benefits based on their INDC's target over the long-run. Important choices are also examined to identify the formulation of best strategies as a region against the threats of global warming. To have a targeted outcome, a dynamic non-linear quantitative model is used to see the ideal projections from 2020 to 2060. Finally, comparative study outcomes are analysed, examining optimal and business as usual approaches, in order to design better strategies in the ASEAN region.

\section{Material And Methods}

This study used modelling analysis with the help of a dynamic environmental multidisciplinary structure combining ecology, earth science and economy[1] to analyse projected climate damage over the long-run.[2] The multidisciplinary structure adopted is a nonlinear dynamic quantitative technique arranging by a 'Dynamic Regional Integrated Model for the Ecology and Economy'. The study model considered all of the INDCs' variables (e.g. future climate visions, green technologies, and investment in capital and vulnerabilities) and country-specific local government climate roadmaps (e.g. emission reduction) from all members in the ASEAN region. The adopted model developed a structure by linking economic growth and climatic alteration variables (i.e. responsible for carbon and other greenhouse gas emissions) with additional variables such as population, energy, and green technological innovations (known as backstop technologies) with the endogenous parameters. By contrast, technological change is considered as an exogenous parameter[3] whereas 'policy thrust' is considered to be an endogenous parameter with a top-down modelling approach. The economic growth in the various ASEAN countries is used as a function of goods and services (GDP) measured by nominal values and current prices. The modelling assumption used in this study followed the Fifth Assessment Report (FAR) (IPCC, 2014; Edenhofer et a., 2014). Other non-carbon emission estimations are carefully modelled after the recent work of Rasiah et al. (2018). The detailed study approaches are indicated below.[4]

\subsection{Study area}

The climatic parameters and measurements utilized in the study experiments are based on data for each of the ASEAN nations. The respective national INDCs are fully considered under each specific government's climate roadmap and future policy thrusts.

\subsection{Technique and Adoption of Method}

The scenario projections closely followed the approach developed by Nordhaus (2008) for the ASEAN region (e.g. see the Appendix for the mathematical modelling). The projections indicate a range of reasonable climatic outcomes from 2020 to 2060 (e.g. $2010-$

Page 6/18 
2019 based on real data and 2020-2060 based on simulations) using inputs about endogenous parameters at the country level. The adopted dynamic modelling approach (e.g. top-down) applied the resulting effects on the ASEAN region (from global climatic outcomes to regional level[5]) where global observational large-scale data are downscaled and set to predict the annual cycle used for:(a) circulation parameters (e.g. the predicted annual cycle of carbon concentrations, climatic effects, damages, etc.), and (b) temperature fluctuations (e.g. annual fluctuations in global warming). Finally, the circulation parameters addressed by Nordhaus (2008) are used as the predicted annual cycle of outcomes by addressing:

(i) Emissions (per year)

(ii) Regional output (including net damages)

(iii) Impacts of climate change (by gross output)

(iv) Carbon price (based on carbon/ton)

(v) Emissions control rate (carbon/ton) and

(vi) Social cost of carbon (carbon/ton)

The estimations of ASEAN nation climatic outcomes are calculated over the long-run using two scenarios, (i) Business as Usual (BAU) (ii) Optimal Scenarios (OS).

\subsection{Data}

Two types of quantitative data were utilized to fill the targeted aims, namely, (i) macroeconomic data collected by the ASEAN Secretariat (ASEAN Facts, 2015), and (ii) meteorological data derived from global models (EU, $2015 \mathrm{JRC} / \mathrm{PBL}$, EDGAR). It is important to realize that this study used real-time meteorological data (e.g. 2 sets) from 2010 to 2019 to populate the scenario projections for 2020- 2060[6]. ASEAN temperature data were taken from EU historical records of GHG concentrations (280-350 parts per million $(\mathrm{ppm})$ ). This study also used projected temperature fluctuations within $2.0^{\circ} \mathrm{C}$ for modelling purposes, by using global climate parameters as indicated by Nordhaus (2008) by (i) atmospheric carbon concentration both non-equilibrium and equilibrium, and initial lower and upper strata, carbon concentration of (ii) temperature variations both non-equilibrium and equilibrium, and initial lower and upper strata, and (vii) damage intercepts by carbon emissions both from OS and BAU parameters.

\subsection{Instrument for Data Analysis}

This study utilized (i) the Syntax Programming (SP) technique and (ii) a General Algebraic Modelling System (GAMS) for data analysis. The GAMS is based on non-nonlinear approach and SP are based on the mixed-integer problem and both are duly used for the projections of climatic outcomes of different climate policies over the years from 2020 to 2060.

\subsection{Climate considerations}

This study plans to do the projections for global warming impacts for ASEAN in the next 40 years (2020-2060). Technologies suggested by Nordhaus (2008) used as initially by BAU where no additional consideration is taken place for mitigating climatic impacts, and finally, Optimal scenario (OS) conditions is engaged as per INDCs for all nations in the ASEAN.

\subsection{The discount rate and carbon price}

This study used a discount rate of $1.45 \%$ for all ASEAN nations to evaluate future costs based on present discount values (PDV). The discount rate was converted mathematically to estimate monetary values for goods and services in Ringgit Malaysia (RM)[7] which was then adjusted for net inflation (i.e. set at 3\%). All necessary input data such as per capita purchasing power (PPP), and net inflation were derived from the ASEAN Secretariat (ASEAN Facts, 2015). Lastly, the cost of carbon emission (CCE) was estimated using the RICE modelling approach, whereas the social cost of carbon (SCC) for GHG emissions are duly considered with net present value (NPV). 


\section{Results And Findings}

The results of the modelling scenarios of ASEAN conditions under BAU and OS from 2020 to 2060 are shown in Table 2. To analyze the climate change scenario this study used a five-year interval over a 40 year time period. The dynamic regional climatic model utilized maintained close intergenerational neutrality to the capital rate of return and resource allocations to estimate calibration for the long-run climate scenarios. The cost of green technologies (known as backstop technologies) is measured based on marginal concepts (i.e. the marginal cost of reducing the last unit of carbon emissions is equal to marginal damage) from 2020 to 2060 . Modelling projections showing the emission scenarios for ASEAN were estimated using marginal utility elasticity of consumption with a social time preference rate of $1.45 \%$ per year from the baseline. The backstop technology is considered duly but the rate of adoption is also used by a business-as-usual amount. Green technology options are not measured drastically to compare the difference of trends of climatic change and impacts between business-as-usual and optimal situation.

Projections until 2060 show that under a BAU Scenario, industrial emissions ( $\mathrm{bTCO}_{2}$ per year) will increase in monetary value gradually from RM5.07 (btCO 2 per year) with a steady growth till it reaches to RM67.60 (btCO2 per year) by 2060 in the ASEAN region (Figure 2). Industry emission under Optimal scenario (OS), on the other hand, will be rising from RM 5.07 (btCO2 per year) in 2020 to RM 12.28 (btCO2 per year) in 2030 and RM 31.99 (btCO2 per year) in 2060. It is observed that under Optimal Scenario (OS) industrial emissions will be lower in 2025, 2030, 2035, 2040, 2045, 2050, 2055 and 2060 compared to the BAU in all segments. The projections (see Table 2) also indicate that atmospheric concentration of carbon under the BAU scenario (PPM) will gradually increase from 303 PPM in 2020 and 351 PPM by 2060. The atmospheric concentration of carbon seems going up initially and does not maintain stability at all and increasing progressively over time with an increasing trend. On the other hand, the atmospheric concentration of carbon under Optimal scenario (OS) will gradually fall from 303 PPM in 2020 to 298 PPM by 2060 . The reduction in the atmospheric concentration of carbon seems going down under OS by restricting carbon emission and seems to maintain stability in the trend by 2060 .

The projections also indicate that atmospheric temperature under BAU (deg C above preindustrial) will rise from 0.76 deg $\mathrm{C}$ in 2020 to $0.77 \mathrm{deg} C$ by 2045 as the temperature cap was not used against temperature rise. Under the same circumstances, atmospheric temperature will rise again from 0.77 in 2045 to 0.79 by 2060 (Table 2). On the other hand, under the Optimal scenario (deg C above preindustrial), atmospheric temperature will fall gradually from $0.76 \mathrm{deg} C$ in 2020 to $0.74 \mathrm{deg}$ C by 2045 and will fall further to 0.70 by 2060. Climate damage under BAU (deg C above preindustrial) scenario is projected to rise gradually from 0.038 deg C in 2020 to 0.977 deg $C$ in 2060 . On the other hand, climate damage is projected to be minimal in the Optimal Scenario, and thus the optimal scenario is static till 2060. Specifically, the study findings indicate that climate damage under an Optimal Scenario (deg C above preindustrial) will be unchanged overall (as indicated $0.002 \mathrm{deg}$ C) in between 2020-2040 and it will be reduced to about 0.001 deg C by 2060. Thus, climate damage will be minimal in the optimal scenario by 2060 .

Table 2: Here direct reason for the implementation of a carbon tax is that this is a condition of the INDCs (Figure 3). In this study, the carbon price ( $\mathrm{RM}$ per $\mathrm{t} \mathrm{CO}_{2}$ ) under the Optimal scenario (OS) is applied from 2035 onwards, with no carbon tax being applied before 2035. The tax is increased gradually with conventional output production until 2060 whereas a carbon tax is not applied at all for a $\mathrm{BAU}$ scenario. The projections from the $\mathrm{OS}$ indicated that carbon prices ( $\mathrm{RM}$ per $\left.\mathrm{t} \mathrm{CO}_{2}\right)$ will increase from RM 230 in 2035 peaking at RM 245 per $\mathrm{tCO}_{2}$ in 2060. Money collected from the $\mathrm{CO}_{2}$ tax can then be reinvested by ASEAN governments in order to implement alternative energy production technologies. The outcome is tempting overall arguments to bring a sustained balance between green development and environment over the long run. Under the OS, industries will gradually switch from conventional energy to zerocarbon energy technologies to avoid the carbon tax over time. The ASEAN secretariat can speed up the carbon emission reduction process using the carbon tax scenario just described, and then use the funds raised to invest in backstop technologies.

A shown in Figure 4, under BAU emission control rates are assumed to be negligible until 2035 and then gradually grow until 2055 with uneven rates thereafter. Under Optimal scenario (OS) however, emission control rates will start to increase by 2030 and will grow rapidly to 0.45 by 2035 and then level off until 2060. In Figure 5, the social cost of carbon (RM/ton)[1] under the BAU scenario over the period 2020-2060 shows a sharp rise for the ASEAN region, rising from RM90 in 2030 to RM55 in 2035, RM224 in 2040, RM552 in 2050, RM571 in 2055, and a very steep rise of RM1,349 by 2060. By comparison, the rise of the social cost of carbon (RM/ton) is insignificant under the optimal scenario (OS). The study indicated that it will be RM1.04 in 2035, RM11.19 in 2040, RM13.73 in 2045, RM23.08 in 2050, and it will drop to RM20.70 in 2055 and remains stable till 2060. Thus, this finding provides support for an OS strategy going forward. 


\section{Policy Implication And Discussion}

According to the 'Paris Agreement', both developing and developed countries have to take action by their own responsibilities and contribute to a unified institutional framework under separate national systems. ASEAN nations are considered as non-Annex-I nations so they must also turn to gap-filling actions in helping global climate agreements achieve the long-term goal to control global temperature rise of less than $2^{\circ} \mathrm{C}$ based on pre-industrial temperatures. Accordingly, ASEAN leaders have embraced the AEC (ASEAN Economic Community) outline which reflects ASEAN's own needs by incorporating responses to climate change into its environmental ingenuity plans and goal to attain sustainable socio-economic development. Thus, this study has explored one possible way forward as the ASEAN region attempts to translate the promised determinants of INDCs of the Paris Agreement into measurable movements, and has examined how ASEAN nations could reduce the climate change threats by 2060 . The findings of this study are significant in the sense that a long-run national 'optimal policy' for controlling carbon emission in the Southeast Asian nations is found to be better on several fronts compared to the scenario of business-as-usual. This study used projections in contrast to the suggested interventions by Mori et al. (2010) and Rosen \& Guenther (2015).

This study found that a carbon tax in addition to backstop technologies would cause reduced carbon emissions eventually as carbon taxes pressure firms to substitute green technologies for conventional ones. By implementing green technologies (e.g. greener energy plants, hydrogen power plants, conversion of water to gas, and green innovation), $\mathrm{CO}_{2}$ emissions which differ from one ASEAN country to another could reach a balanced level over time. Furthermore, the study suggests that by 2045-2055, ASEAN region could reach a balanced level in terms of carbon emissions, carbon tax, emissions control and carbon price under the Optimal scenarios (OS). Forced implementation of climatic actions and adjustment of a carbon tax and backstop technologies will also enable environmental residues to be converted into greener by-products which may add additional value. The findings from the OS are found to be similar in nature as the earlier study by Míguez et al. (2018).

Therefore, we suggest a policy overhaul following Optimal scenarios (OS) that raise the cost of destructive emissions, which in turn motivates the production and invention of backstop technologies that will eventually benefit countries looking for policies to mitigate climatic impacts. As stated in studies by Stern (2007) and Nordhaus (2008), to accelerate the replacement of conventional technologies with environmentally-friendly ones, the imposition of a carbon tax is worth exploring. Other recent studies by Rasiah et al. $(2017 ; 2018)$ and Sarkar et al. (2019) anticipate mitigating climatic impacts on ASEAN through approaches applied in this study and additional ideas which are based on recent ASEAN needs. Therefore, to accelerate uptake of zero-carbon technologies throughout the ASEAN region, the secretariat of ASEAN should speed up the practice of collecting revenue from a carbon tax to subsidize the full process of the replacement of conventional technologies by greener ones from 2030 onwards.

Unless ASEAN nations participate fully in INDCs and climate mitigation actions, climatic change will not be reduced under businessas-usual actions. Thus, this study explains that ASEAN's business-as-usual scenarios will not reduce climate change losses over the period examined unless there is full commitment to an optimum policy in the region. Moreover, as is obvious from the study outcomes, without sustained interventions, the aggregate costs of social damage in the region will rise throughout the century. The findings are echoed in the extensive study of Stern (2007).

Therefore, to mitigate damages as well as reduce emission levels, an optimal policy of climate change actions should be followed in order to make available extra carbon tax income and reduce the long-term impact of climate change widely in the ASEAN region. A similar idea was proposed long ago by Harding (1968) who suggested that adopting an optimal control policy widely can save the environment which is shared globally. Thus, this study is important for ASEAN policymakers dealing with the protection policy of global climate as well as uncertainty about the costs of climate mitigation in the region. As national contributors to the Paris agreement, ASEAN nations need a clearer vision of how to switch paths for specific sectors, and how to trigger associated benefits. As suggested in this study, $\mathrm{CO}_{2}$ emission reduction targets ought to be outlined properly in the ASEAN region without delay by doing comparative studies of BAU and Optimal scenarios (OS).

However, climate change can not be controlled without proper support from all world leaders simultaneously, and support from international agents will play a vital role in reducing carbon emissions as actively contributing to the respective economy under rigorous emissions reduction targets (Ruamsuke et al., 2015; Cao \& Ward, 2017). Already, six ASEAN economies (Brunei, Philippines, Indonesia, Malaysia, Thailand and Singapore) are planned to advanc rigorously backstop technologies in the next decades (Rasiah et al., 2018). Such countries should also share their technologies and with their neighbouring countries including Cambodia, Myanmar, 
Lao PDR, Timor Leste and Vietnam. South-south transfer of regional knowledge could help to accelerate efficiency gains on backstop technologies required against actions of climatic mitigation in the overall ASEAN region.

\section{Conclusions}

This comparative study between Optimal scenario (OS) and BAU shows the relative climatic vulnerability assessments on the ASEAN region with and without optimal climate policies, and explores the climate mitigation impacts over the long run. The findings of the comparative measurement clearly show what actions are imperative, and which strategies should be taken for climate change mitigation to slow down future climate change-related emissions. The study projections from 2020-2060 provide substantial knowledge of ASEAN future actions on a regional long-term climate strategies. The study outcomes provide guidelines on how climatic emissions will slow down with green technological innovation and greener energy alternatives. This study advocates effective strategies for climate mitigation and explains why the ASEAN region should proceed with invention of backstop technologies from 2020 to 2060 to slow down climatic impacts. The Optimal scenario points out arguments to bring a balance between sustainable development and environment over the long run. The ASEAN secretariat can quicken the carbon emission reduction process over time by using carbon tax as detailed in the scenario projections, and can use carbon tax funding to implement zero-carbon technologies as backstop technological innovations.

\section{References}

Ahmed, A., Al-Amin, A. Q., \& Rasiah, R. (2019). COP negotiations and Malaysian climate change roadmap: a comparative assessment using a dynamic environmental model. Environmental Science and Pollution Research, 26(29), 30003-30015.

Al-Amin, A. Q., \& Filho, W. L. (2014). A return to prioritizing needs: Adaptation or mitigation alternatives? Progress in Development Studies, 14(4), 359-371.

Al-Amin, A. Q., Rasiah, R., \& Chenayah, S. (2015). Prioritizing climate change mitigation: an assessment using Malaysia to reduce carbon emissions in future. Environmental Science \& Policy, 50, 24-33.

Amran, A., Ooi, S. K., Wong, C. Y., \& Hashim, F. (2016). Business strategy for climate change: An ASEAN perspective. Corporate Social Responsibility and Environmental Management, 23(4), 213-227.

Ang, B. W., \& Goh, T. (2016). Carbon intensity of electricity in ASEAN: Drivers, performance and outlook. Energy Policy, 98, 170-179.

Auffhammer, M. (2018). Quantifying economic damages from climate change. Journal of Economic Perspectives, 32(4), 33-52.

Bakhtyar, B., Sopian, K., Sulaiman, M. Y., \& Ahmad, S. A. (2013). Renewable energy in five South East Asian countries: Review on electricity consumption and economic growth. Renewable and Sustainable Energy Reviews, 26, 506-514.

Bataille, C. G. (2020). Physical and policy pathways to net-zero emissions industry. Wiley Interdisciplinary Reviews: Climate Change, 11(2), e633.

Bernstein, L., Bosch, P., Canziani, O., Chen, Z., Christ, R., Davidson, O., \& Yohe, G. (2007). Climate change 2007: Summary for policymakers. Hemisphere, 57(8), 267-269.

Bodansky, D. (2016). The Paris climate change agreement: a new hope?. American Journal of International Law, 110(2), 288-319.

Boeker, E., \& Van Grondelle, R. (2011). Environmental physics: sustainable energy and climate change. John Wiley \& Sons.

Bonfils, C., Duffy, P. B., Santer, B. D., Wigley, T. M., Lobell, D. B., Phillips, T. J., \& Doutriaux, C. (2008). Identification of external influences on temperatures in California. Climatic Change, 87(1), 43-55.

Burch, S., \& Robinson, J. (2007). A framework for explaining the links between capacity and action in response to global climate change. Climate Policy, 7(4), 304-316.

Cai, Y., Sam, C. Y., \& Chang, T. (2018). Nexus between clean energy consumption, economic growth and CO2 emissions. Journal of Cleaner Production, 182, 1001-1011. 
Cao, X., \& Ward, H. (2017). Transnational climate governance networks and domestic regulatory action. International Interactions, 43(1), 76-102.

De Vries, B. J., Van Vuuren, D. P., \& Hoogwijk, M. M. (2007). Renewable energy sources: Their global potential for the first-half of the 21 st century at a global level: An integrated approach. Energy Policy, 35(4), 2590-2610.

DeConto, R. M., \& Pollard, D. (2016). Contribution of Antarctica to past and future sea-level rise. Nature, 531(7596), 591-597.

Edenhofer O, Pichs-Madruga R, Sokona Y, Farahani E, Kadner S, Seyboth K, et al. (2014). Summary for policymakers. In: Climate change 2014. Mitigation of climate change. Contribution of Working Group III to the Fifth Assessment Report of the Intergovernmental Panel on Climate Change. Cambridge: Cambridge University Press.

EU EC. (2015). The EDGAR 3.2 database. Available from: http://themasites.pbl.nl/tridion/en/themasites/edgar/emission_data/index2.html. Accessed on 12 Dec 2019.

Foo, K. Y. (2015). A vision on the opportunities, policies and coping strategies for the energy security and green energy development in Malaysia. Renewable and Sustainable Energy Reviews, 51, 1477-1498.

Francesch-Huidobro, M. (2016). Climate change and energy policies in Shanghai: A multilevel governance perspective. Applied Energy, $164,45-56$.

Fu, C.-B. (2007). Addressing climate change scientifically. Sci. Technol. Rev. 25 (14) (Foreword, in Chinese).

Gao, Y. (2016). China's response to climate change issues after Paris Climate Change Conference. Advances in Climate Change Research, 7(4), 235-240.

Hamilton, M., Lubell, M., \& Namaganda, E. (2018). Cross-level linkages in an ecology of climate change adaptation policy games. Ecology and Society, 23(2).

Herring, H. (2006). Energy efficiency-a critical view. Energy, 31(1), 10-20.

Hertzberg, M., Siddons, A., \& Schreuder, H. (2017). Role of greenhouse gases in climate change. Energy \& Environment, 28(4), 530-539.

Hoad, D. (2015). Reflections on small island states and the international climate change negotiations (COP21, Paris, 2015). Island Studies Journal, 10(2), 259-262.

Holden, E., Linnerud, K., \& Banister, D. (2017). The imperatives of sustainable development. Sustainable Development, 25(3), $213-226$.

IEA (2015). Energy and Climate Change: World Energy Outlook Special Report. Available from:

http://wedocs.unep.org/bitstream/handle/20.500.11822/18805/WEO2015_Special_Report_on_Energy_and_Climate_Change.pdf? sequence=1\&isAllowed=y. Accessed on 12 Dec 2019.

IEA (2016). World Energy Outlook 2016. In: IEA.

IEA (2018). The Global Energy Demand and CO2 Status Report, In: IEA.

INDC (2019). INDCs as communicated by Parties. Available from:

http://www4.unfccc.int/submissions/indc/Submission\%20Pages/submissions.aspx. Accessed on 12 Dec 2019.

IPCC (2014). Climate Change 2014: Synthesis Report. Cambridge: Cambridge University Press.

James, R., Washington, R., Schleussner, C. F., Rogelj, J., \& Conway, D. (2017). Characterizing half-a-degree difference: a review of methods for identifying regional climate responses to global warming targets. Wiley Interdisciplinary Reviews: Climate Change, 8(2), e457.

Jewell, J., Vinichenko, V., Nacke, L., \& Cherp, A. (2019). Prospects for powering past coal. Nature Climate Change, 9(8), 592-597.

Keohane, R. O., \& Victor, D. G. (2016). Cooperation and discord in global climate policy. Nature Climate Change, 6(6), 570-575. 
Klepp, S. (2017). Climate change and migration. In Oxford research encyclopedia of climate science.Oxford, UK.

Kok, M., Metz, B., Verhagen, J., \& Van Rooijen, S. (2008). Integrating development and climate policies: national and international benefits. Climate Policy, 8(2), 103-118.

Lau, W. K., \& Kim, K. (2010). Response of the water cycle of West Africa and Atlantic to Radiative Forcing by Saharan Dust. In: AGU Fall Meeting Abstracts, December.

Li, J. F., Gu, A. L., Ma, Z. Y., Zhang, C. L., \& Sun, Z. Q. (2019). Economic development, energy demand, and carbon emission prospects of China's provinces during the 14th Five-Year Plan period: Application of CMRCGE model. Advances in Climate Change Research, 10(3), 165-173.

Manabe, S. (2019). Role of greenhouse gas in climate change. Tellus A: Dynamic Meteorology and Oceanography, 71(1), 1-13.

Meadows, D. H., Meadows, D. L., Randers, J., \& Behrens, W. W. (1972). The Limits to Growth, A Report of The Club of Rome's Project on the Predicament of Mankind. New York: Universe Books.

Míguez, J. L., Porteiro, J., Pérez-Orozco, R., Patiño, D., \& Rodríguez, S. (2018). Evolution of CO2 capture technology between 2007 and 2017 through the study of patent activity. Applied Energy, 211, 1282-1296.

Muradov, N. (2014). Introduction to Carbon Civilization. In Liberating Energy from Carbon: Introduction to Decarbonization (pp. 1-42). Springer, New York, NY.

Murillo, S., Miguez, J. L., Porteiro, J., Hernández, J. J., \& López-González, L. M. (2003). Viability of LPG use in low-power outboard engines for reduction in consumption and pollutant emissions. International Journal of Energy Research, 27(5), 467-480.

Mycoo, M., Donovan, M. G., Mycoo, M., Donovan, M. G., Mycoo, M., Donovan, M. G., ... \& Donovan, M. G. (2017). A blue urban agenda: adapting to climate change in the coastal cities of Caribbean and Pacific Small Island Developing States.

Nerem, R. S., Beckley, B. D., Fasullo, J. T., Hamlington, B. D., Masters, D., \& Mitchum, G. T. (2018). Climate-change-driven accelerated sea-level rise detected in the altimeter era. Proceedings of the National Academy of Sciences, 115(9), 2022-2025.

Nordhaus, W. D. (2001). Global warming economics. Science, 294, 1283- 1284.

Nordhaus, W. D. (2008). A question of balance: Weighing the options on global warming policies. New Haven, CT: Yale University Press.

O’Neill, B.C., Kriegler, E., Riahi, K., Ebi, K.L., Hallegatte, S., Carter, T.R. Mathur, R. Vuuren, D.P. (2014). A new scenario framework for climate change research: the concept of shared socioeconomic pathways. Climatic Change, 122 (3), 387-400.

Olivier, J. G., Schure, K. M., \& Peters, J. A. H. W. (2017). Trends in global CO2 and total greenhouse gas emissions. PBL Netherlands Environmental Assessment Agency, 5.

Owusu, P. A., \& Asumadu-Sarkodie, S. (2016). A review of renewable energy sources, sustainability issues and climate change mitigation. Cogent Engineering, 3(1), 1167990.

Palm, J., \& Thollander, P. (2010). An interdisciplinary perspective on industrial energy efficiency. Applied Energy, 87(10), $3255-3261$.

Panayotou, T. (1997). Emerging Asia: Environment and Natural Resources. In: Emerging Asia: Changes and Challenges. Manila: Asian Development Bank, 2, Part 4.

Patiño, D., Crespo, B., Porteiro, J., \& Míguez, J. L. (2016). Experimental analysis of fouling rates in two small-scale domestic boilers. Applied Thermal Engineering, 100, 849-860.

Patiño, D., Moran, J., Porteiro, J., Collazo, J., Granada, E., \& Miguez, J. L. (2008). Improving the cofiring process of wood pellet and refuse derived fuel in a small-scale boiler plant. Energy \& Fuels, 22(3), 2121-2128. 
Rasiah, R., Ahmed, A., Al-Amin, A. Q., \& Chenayah, S. (2017). Climate change mitigation: comparative assessment of Malaysian and ASEAN scenarios. Environmental Science and Pollution Research, 24(3), 2632-2642.

Rasiah, R., Al-Amin, A. Q., Chowdhurry, A. H., Ahmed, F., \& Zhang, C. (2018). Climate change mitigation projections for ASEAN. Journal of the Asia Pacific Economy, 23(2), 195-212.

Read, P. (2016). Communication Failures in Climate Policy: Complementary Action on Abrupt Climate Change. Global Warming and Climate Change (2 Vols.): Ten Years after Kyoto and Still Counting, 155.

Ritchie H \& Roser M (2020). "Energy". Published online at OurWorldInData.org. Retrieved from: 'https://ourworldindata.org/energy' access date May 12, 2020 [Online Resource]

Rogelj, J., Hare, W., Lowe, J., Van Vuuren, D. P., Riahi, K., Matthews, B., Hanaoka T, Jiang K., \& Meinshausen, M. (2011). Emission pathways consistent with a $2 \mathrm{C}$ global temperature limit. Nature Climate Change, 1(8), 413.

Ruamsuke, K., Dhakal, S., \& Marpaung, C. O. (2015). Energy and economic impacts of the global climate change policy on Southeast Asian countries: A general equilibrium analysis. Energy, 81, 446-461.

Sachs, J. D. (2015). The Age of Sustainable Development. New York: Columbia University Press.

Salahuddin, M., Alam, K., \& Ozturk, I. (2016). The effects of Internet usage and economic growth on CO2 emissions in OECD countries: A panel investigation. Renewable and Sustainable Energy Reviews, 62, 1226-1235.

Sarkar, M. S. K., Al-Amin, A. Q., \& Leal Filho, W. (2019). Revisiting the social cost of carbon after INDC implementation in Malaysia: 2050. Environmental Science and Pollution Research, 26(6), 6000-6013.

Seddon, N., Chausson, A., Berry, P., Girardin, C. A., Smith, A., \& Turner, B. (2020). Understanding the value and limits of nature-based solutions to climate change and other global challenges. Philosophical Transactions of the Royal Society B, 375(1794), 20190120.

Serrano-Ruiz, J. C., \& Dumesic, J. A. (2011). Catalytic routes for the conversion of biomass into liquid hydrocarbon transportation fuels. Energy \& Environmental Science, 4(1), 83-99.

Stern, N. (2007). The Economics of Climate Change: The Stern review. Cambridge: Cambridge University press.

Sun, Y., Qin, D. H., \& Liu, H. B. (2012). Introduction to Treatment of Uncertainties for IPCC Fifth Assessment Report. Progressus Inquisitiones De Mutatione Climatis, 8(2), 150-153.

UNFCCC (2015). Adoption of the Paris Agreement. Decision 1/CP.21. Paris Agreement. Available from:

http://unfccc.int/files/essential_background/convention/application/pdf/chinese_paris_agreement.pdf. Accessed on 12 Dec 2019.

UNFCCC (2016). Marrakesch Climate Change Conference - November 2016. Available from: http://unfccc.int/meet ings/marrakech_nov_2016/meeting/9567.php. Accessed on 12 Dec 2019.

Uy, N., \& Shaw, R. (2010). Climate change adaptation in ASEAN: Actions and challenges. Climate change adaptation and disaster risk reduction: Issues and challenges, 349-368.

Vandenbergh, M. P., \& Gilligan, J. M. (2017). Beyond Politics. Cambridge University Press.

Vousdoukas, M. I., Mentaschi, L., Voukouvalas, E., Verlaan, M., \& Feyen, L. (2017). Extreme sea levels on the rise along Europe's coasts. Earth's Future, 5(3), 304-323.

Wang, Y., Chen, L., \& Kubota, J. (2016). The relationship between urbanization, energy use and carbon emissions: evidence from a panel of Association of Southeast Asian Nations (ASEAN) countries. Journal of Cleaner Production, 112, $1368-1374$.

Wijffels, S., Roemmich, D., Monselesan, D., Church, J., \& Gilson, J. (2016). Ocean temperatures chronicle the ongoing warming of Earth. Nature Climate Change, 6(2), 116-118. 
WMO (2015). Greenhouse Gas Bulletin, the State of Greenhouse Gases in the Atmosphere Based on Global Observations through 2014. Geneva, Switzerland.

World Bank (2017). World Development Indicators. Washington, DC: World Bank Institute.

Yang, H., Xu, Z., Fan, M., Gupta, R., Slimane, R. B., Bland, A. E., \& Wright, I. (2008). Progress in carbon dioxide separation and capture: A review. Journal of Environmental Sciences, 20(1), 14-27.

Yao, F., Qin, P., Zhang, J., Lin, E., \& Boken, V. (2011). Uncertainties in assessing the effect of climate change on agriculture using model simulation and uncertainty processing methods. Chinese Science Bulletin, 56(8), 729-737.

\section{Tables}

Table 1: INDC Reduction Target for ASEAN Member Countries

\begin{tabular}{|lll|}
\hline No & Country & Targeted Reduction \\
\hline 1 & Indonesia & $29 \%$ (unconditional) and $12 \%$ (conditional) by 2030 \\
\hline 2 & Brunei Darussalam & $63 \%$ reduction in total energy consumption by 2035 \\
\hline 3 & Lao PDR & unconditional measures in multiple sectors by 2030 \\
\hline 4 & Malaysia & $35 \%$ (unconditional) and $10 \%$ (conditional) by 2030 \\
\hline 5 & Myanmar & unconditional measures in multiple sectors by 2030 \\
\hline 6 & Cambodia & $27 \%$ (conditional) \\
\hline 7 & Singapore & $36 \%$ (general) by 2030 \\
\hline 8 & Vietnam & $8 \%$ (unconditional) and $17 \%$ (conditional) by 2030 \\
\hline 9 & Thailand & $20 \%$ (unconditional) and $5 \%$ (conditional) by 2030 \\
\hline 10 & Philippines & $70 \%$ (conditional) by 2030 \\
\hline
\end{tabular}

Source: Rasiah et al., (2018); INDC (2019)

Table 2: The BAU and Optimal Scenario data derived from the model ${ }^{1}$

${ }^{1}$ US \$1= RM4.15 used in the study calculations

\section{Figures}




\begin{tabular}{|c|c|c|c|c|c|c|c|c|c|}
\hline Year & 2020 & 2025 & 2030 & 2035 & 2040 & 2045 & 2050 & 2055 & 2060 \\
\hline $\begin{array}{l}\text { Industrial } \\
\text { Emissions } \\
\text { BAU (bTCO2 } \\
\text { per year) }\end{array}$ & 5.072194 & 8.079693 & 12.13338 & 18.02251 & 24.77772 & 34.75644 & 43.81194 & 58.8953 & 67.60486 \\
\hline $\begin{array}{l}\text { Industrial } \\
\text { Emissions } \\
\text { Optimal } \\
\text { (bTCO2 per } \\
\text { year) }\end{array}$ & 5.089325 & 8.064487 & 12.28801 & 9.935614 & 14.05047 & 19.27744 & 23.32478 & 30.21415 & 31.99253 \\
\hline $\begin{array}{l}\text { Atmospheric } \\
\text { concentration } \\
\text { of carbon } \\
\text { BAU (ppm) }\end{array}$ & 303.8078 & 307.1894 & 308.5821 & 309.4664 & 309.779 & 310.9989 & 326.4213 & 335.3765 & 351.2965 \\
\hline $\begin{array}{l}\text { Atmospheric } \\
\text { concentration } \\
\text { of carbon } \\
\text { Optimal } \\
\text { (ppm) }\end{array}$ & 303.8056 & 303.2005 & 302.5713 & 302.1701 & 301.5921 & 300.1826 & 299.2135 & 298.8736 & 298.0875 \\
\hline $\begin{array}{l}\text { Atmospheric } \\
\text { Temperature } \\
\text { BAU (deg C } \\
\text { above } \\
\text { preindustrial) }\end{array}$ & 0.760702 & 0.760448 & 0.764321 & 0.769186 & 0.771774 & 0.777282 & 0.773715 & 0.780708 & 0.794741 \\
\hline $\begin{array}{l}\text { Atmospheric } \\
\text { Temperature } \\
\text { Optimal (deg } \\
\text { C above } \\
\text { preindustrial) }\end{array}$ & 0.760717 & 0.760466 & 0.754317 & 0.759378 & 0.752867 & 0.746993 & 0.735726 & 0.721778 & 0.707151 \\
\hline $\begin{array}{l}\text { Climate } \\
\text { Damages } \\
\text { BAU (fraction } \\
\text { of gross } \\
\text { output) }\end{array}$ & 0.038266 & 0.055647 & 0.085259 & 0.118815 & 0.184345 & 0.255751 & 0.413241 & 0.580202 & 0.976743 \\
\hline $\begin{array}{l}\text { Climate } \\
\text { Damages } \\
\text { Optimal } \\
\text { (fraction of } \\
\text { gross output) }\end{array}$ & 0.001545 & 0.001348 & 0.001287 & 0.001161 & 0.001173 & 0.001083 & 0.001183 & 0.001134 & 0.001335 \\
\hline $\begin{array}{l}\text { Consumption } \\
\text { Per Capita } \\
\text { BAU } \\
\text { (thousand } \\
\text { RM per year) }\end{array}$ & 13.01391 & 17.44907 & 23.34247 & 31.03592 & 40.88609 & 53.39929 & 69.01568 & 88.47454 & 112.2673 \\
\hline $\begin{array}{l}\text { Consumption } \\
\text { Per Capita } \\
\text { Optimal } \\
\text { (thousand } \\
\text { RM per year) }\end{array}$ & 13.05278 & 17.53257 & 23.39224 & 31.10715 & 40.93003 & 53.72151 & 69.49166 & 89.97132 & 114.5237 \\
\hline $\begin{array}{l}\text { Carbon Price } \\
\text { BAU (RM per } \\
\text { t CO2) }\end{array}$ & 0 & 0 & 0 & 0 & 0 & 0 & 0 & 0 & 0 \\
\hline $\begin{array}{l}\text { Carbon Price } \\
\text { Optimal (RM } \\
\text { per t CO2) }\end{array}$ & 0 & 0 & 0 & 230.4167 & 224.6563 & 219.0399 & 258.1614 & 251.7074 & 245.4147 \\
\hline $\begin{array}{l}\text { Emissions } \\
\text { Control Rate } \\
\text { BAU (total) }\end{array}$ & 0 & 0 & 0 & 0.009465 & 0.042952 & 0.027512 & 0.087581 & 0.065098 & 0.164379 \\
\hline $\begin{array}{l}\text { Emissions } \\
\text { Control Rate }\end{array}$ & 0 & 0 & 0 & 0.45 & 0.45 & 0.45 & 0.5 & 0.5 & 0.5 \\
\hline
\end{tabular}




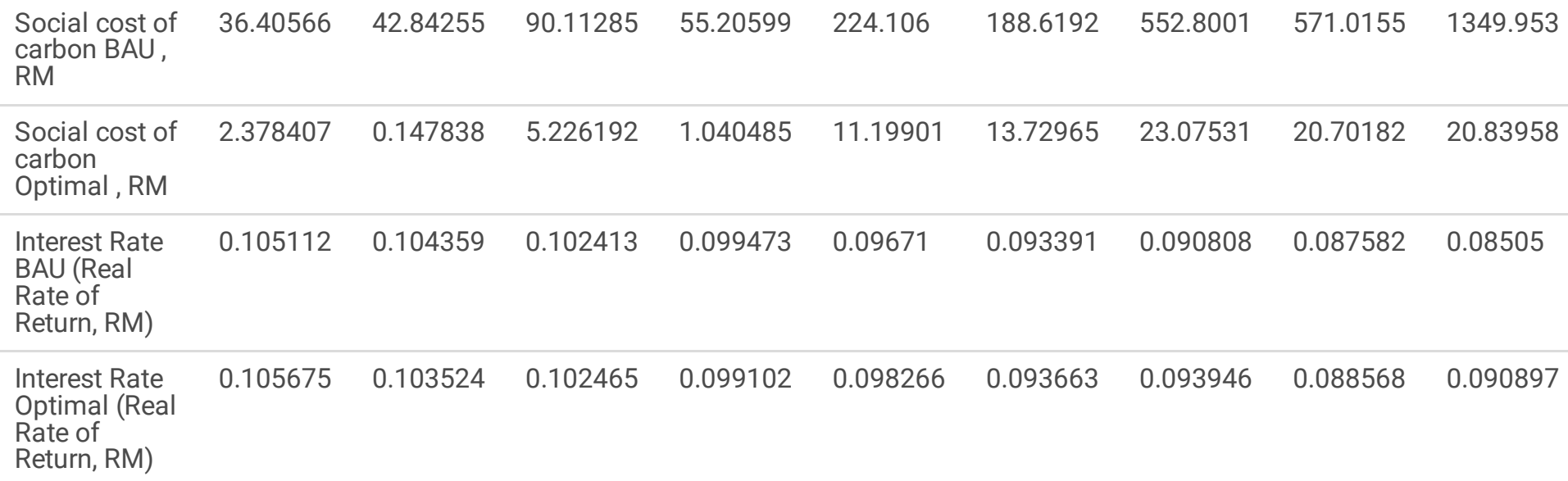

carbon
Optimal , RM

Interest Rate

BAU (Real

$\begin{array}{lllllllll}0.105112 & 0.104359 & 0.102413 & 0.099473 & 0.09671 & 0.093391 & 0.090808 & 0.087582 & 0.08505\end{array}$

Rate of

Return, RM)

Interest Rate

Optimal (Real

$0.105675 \quad 0.103524$

0.102465

$0.099102 \quad 0.098266$

0.093663

0.093946

0.088568

0.090897

Rate of

Return, RM)

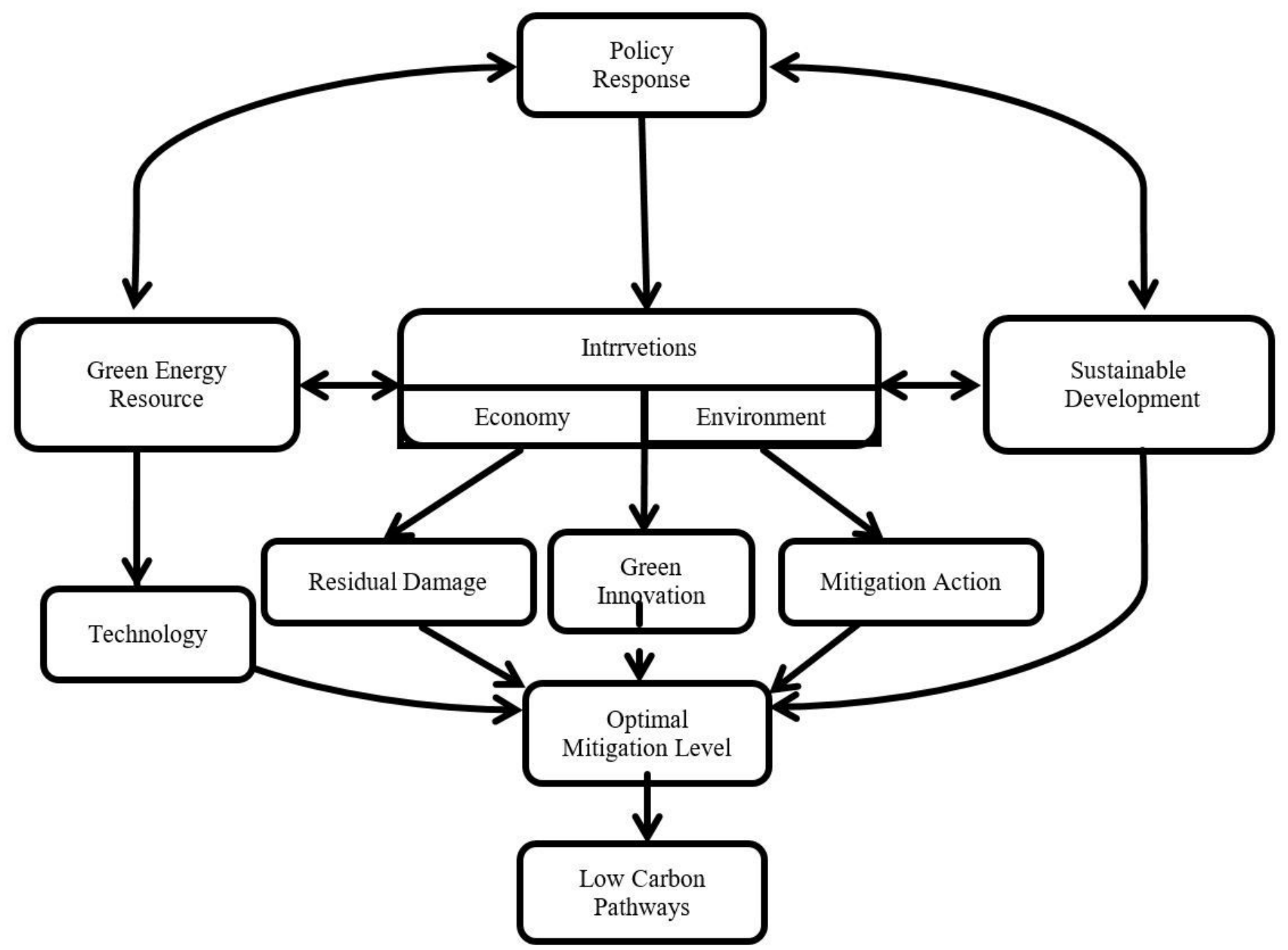

Figure 1

Policy response between climate change and low carbon pathways Source: Authors 


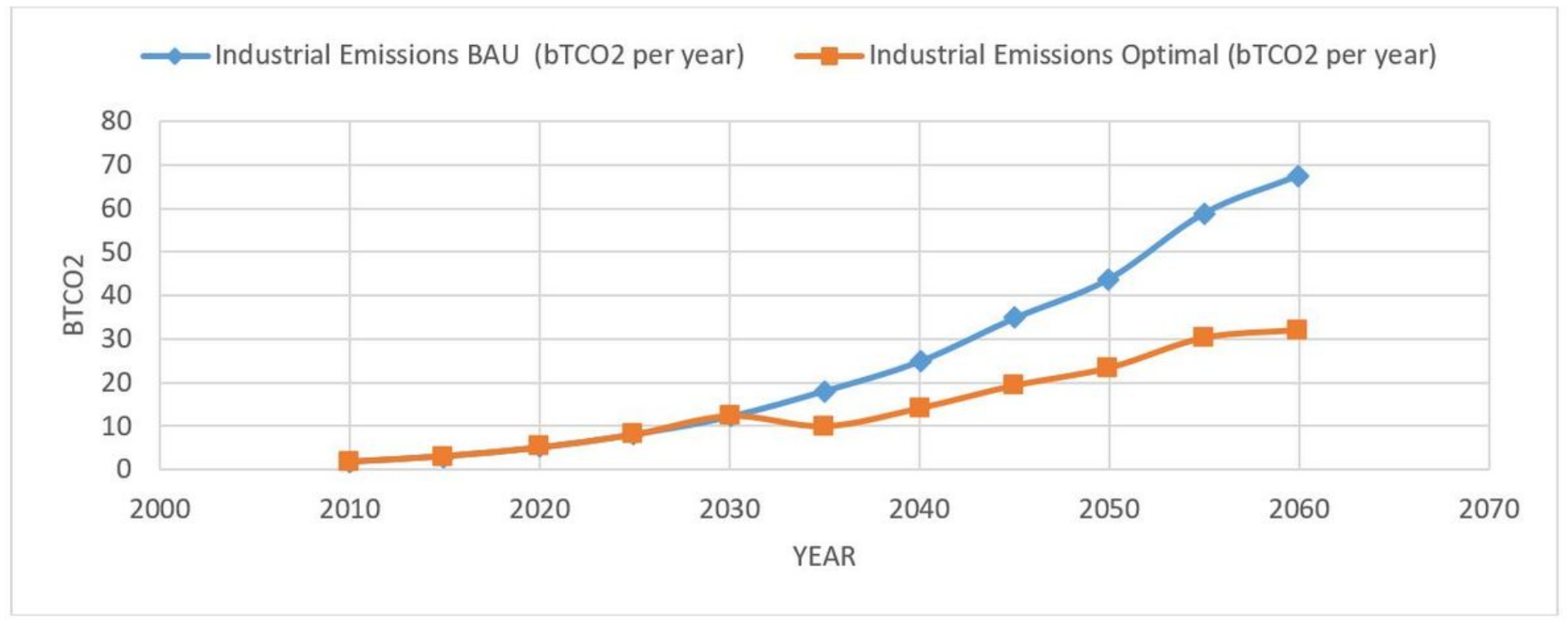

\section{Figure 2}

Industrial emission projections under BAU and Optimal scenario for ASEAN

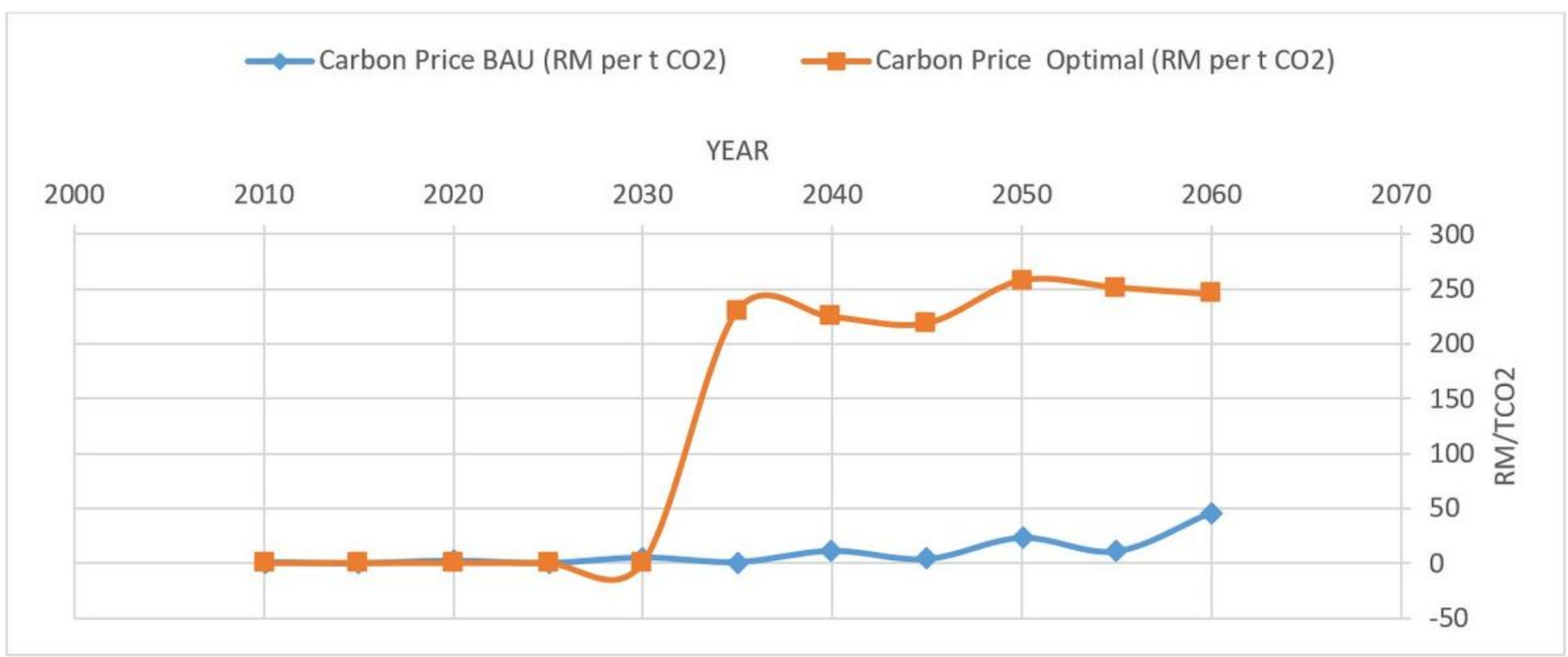

Figure 3

Carbon price (RM per t $\mathrm{CO} 2$ ) under BAU and Optimal scenario 


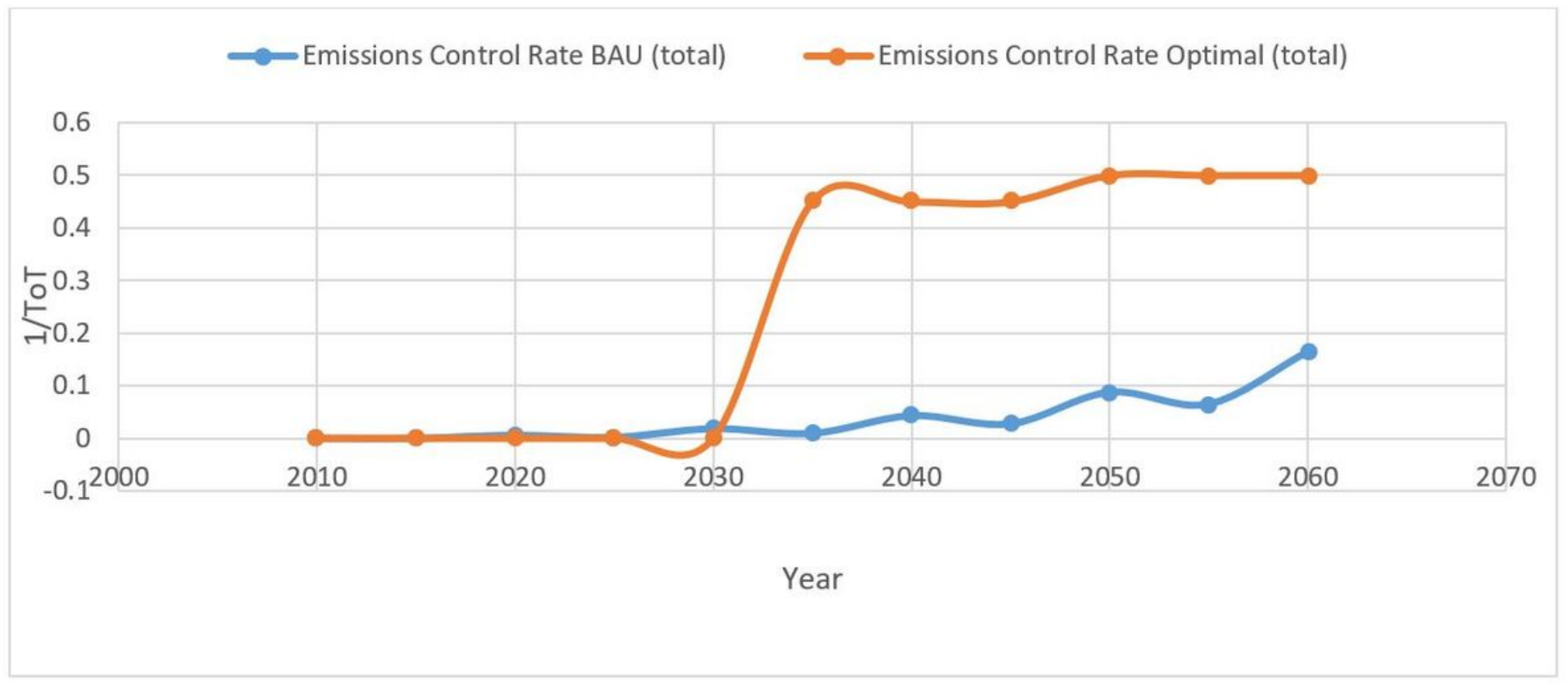

Figure 4

Emission control rate (1/Total) under BAU and Optimal scenario

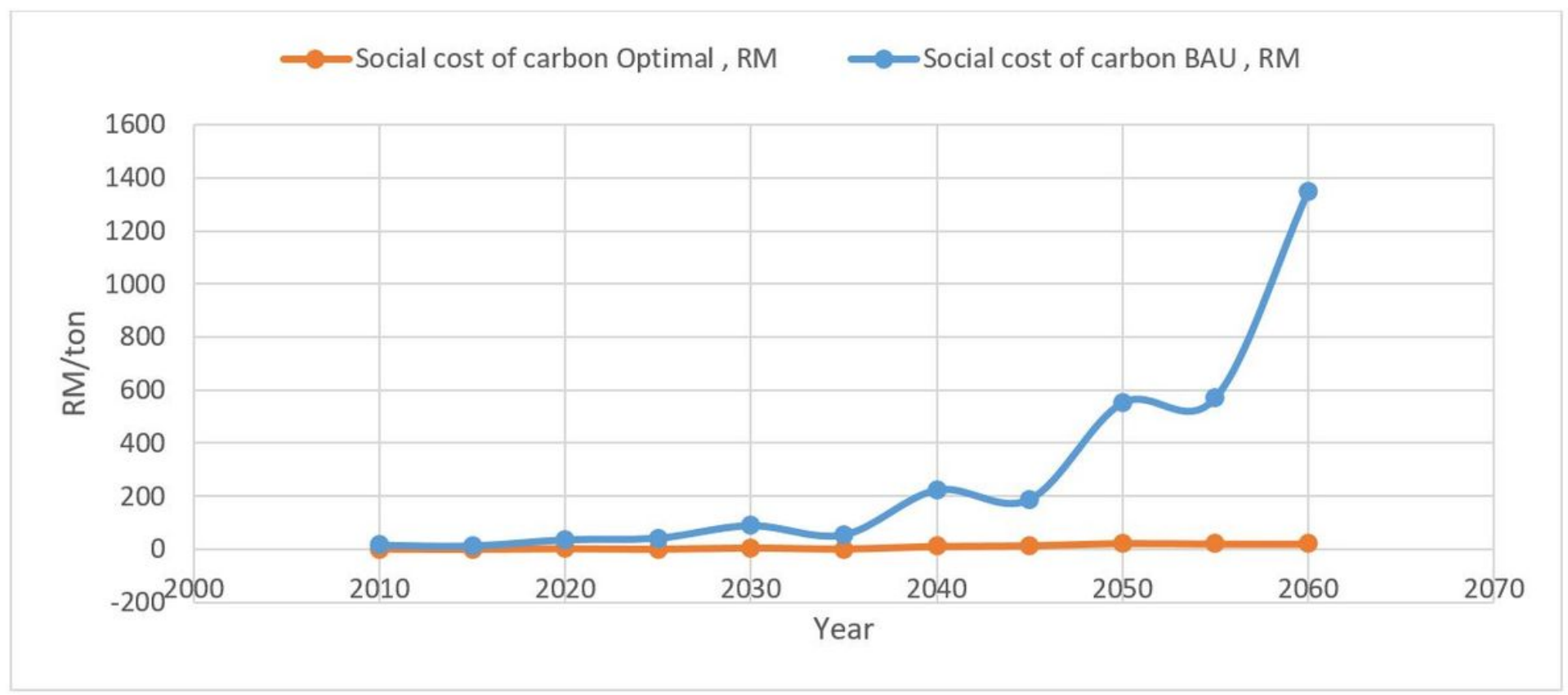

Figure 5

Social cost of carbon (RM/ton) under BAU and Optimal scenario

\section{Supplementary Files}

This is a list of supplementary files associated with this preprint. Click to download.

- Appendix.docx 